\title{
Effect of Induced Mastitis on Disposition Kinetics of Gatifloxacin Following Intravenous Administration in Goats
}

\author{
Vishakha Singh ${ }^{1}$, Mahendra Ram ${ }^{1}$, Birendra Kumar Roy ${ }^{1 *}$ and Kaushal Kumar Singh ${ }^{2}$ \\ ${ }^{1}$ Dept. of Pharmacology \& Toxicology, College of Veterinary Science \& A. H., Ranchi -834006, Jharkhand, India \\ ${ }^{2}$ Dept. of Veterinary pathology, College of Veterinary Science \& A. H., Ranchi-834006, Jharkhand, India
}

\begin{abstract}
Disposition kinetic studies of gatifloxacin (GAT) was conducted after single i.v. dose $(10 \mathrm{mg} / \mathrm{kg})$ in six healthy and six mastitic Black Bengal lactating goats. Mastitis was induced by coagulase positive $S$. aureus. The concentration of the drug was estimated by HPLC. The maximum milk concentration was found to be significantly $(p<0.05)$ higher in mastitic goats $(12.78 \pm 3.11 \mu \mathrm{g} / \mathrm{ml})$ than healthy $(9.17 \pm 1.41 \mu \mathrm{g} / \mathrm{ml})$. The therapeutic milk concentration in mastitic goats $(0.13$ \pm 0.05 to $12.41 \pm 2.99 \mu \mathrm{g} / \mathrm{ml})$ was maintained for $48 \mathrm{~h}$ which was significantly $(p<0.01)$ longer than in healthy goats $(24$ h). The elimination half-life in plasma and milk of mastitic goats $(5.82 \pm 0.67$ and $8.20 \pm 0.21 \mathrm{~h})$ was significantly $(p<0.01)$ higher than healthy $(4.54 \pm 0.75$ and $3.67 \pm 0.09 \mathrm{~h})$.It indicates that GAT persisted in the body of mastitic goats for a longer duration. The $A \cup C_{\text {milk }} / A \cup C_{\text {plasma }}$ ratio was 5.82. The $t_{1 / 2}$ milk $/ t_{1 / 2}$ plasma ratio was 1.41. MIC in this experiment was considered to be $0.1 \mu \mathrm{g} / \mathrm{ml}$. The AUC/MIC ratio of plasma and milk of mastitic goats were 180 and 1049 respectively. On the basis of the results obtained it was concluded that GAT exhibited improved pharmacokinetic parameters with good penetration and longer persistence in mastitic milk, which will be of great help in the treatment of mastitis in goats caused by S. aureus.
\end{abstract}

Keywords: Disposition kinetics; Gatifloxacin; Goats; Mastitis; i.v.

\section{Introduction}

Gatifloxacin (GAT), a fourth generation fluoroquinolone, selectively inhibits bacterial enzymes DNA gyrase and Topoisomerase IV (Perry et al., 1999). Fluoroquinolones have some favourable characteristics such as large volume of distribution, low plasma protein binding, and relatively low MIC against susceptible target microorganisms (Brown, 1996). The MIC value of GAT against Staphylococci has been reported to be $0.1 \mu \mathrm{g} / \mathrm{ml}$ (Tsurumaki et al., 2000; Boubakar et al., 2006). GAT has a chiral center in its structure, exists in plasma as two equi-active equi-proportional R- and S-enantiomers (Wise et al., 1999). Fluoroquinolones act by a concentration-dependent killing mechanism (Drusano et al., 1993), which is associated with a relatively prolonged postantibiotic effect (Aliabadi and Lees, 2001).

Mastitis is a worldwide problem among lactating animals from both economical and public health point of view. In most of the clinical cases of mastitis in goats Staphylococcus aureus is the causative agent (Shearer and Harris, 2008). S. aureus is susceptible to a variety of antibiotics in-vitro. However, the potential contributors to the poor response of $S$. aureus to antimicrobial in-vivo cure may be its ability to survive inside neutrophils (Yancey et al., 1991; Mullarky et al., 2001), and to invade into mammary epithelial cells (Kerro Dogo et al., 2002). The ability to survive phagocytosis by neutrophils protects the bacteria even if they are exposed to the host immune response, except in the case of antibiotics that penetrate intracellularly (Barkema et al., 2006). Fluoroquinolones are widely studied to display intracellular bioactivity against bacteria which reside and/or multiply within phagocytes (Staphylococcus aureus, Legionella pneumophila, mycobacteria, chlamydiae etc). For most of the fluoroquinolones the uptake by phagocytes is moderate and rapid (Loo et al., 1997; Memin et al., 1997). Thus it is expected that GAT would be effective in treating $S$. aureus mastitis. It has also been evidenced that mastitis has an effect on the milk concentrations of antimicrobials in goats (Sar et al., 2006). Limited pharmacokinetic parameters of GAT are available in healthy goats (Verma and Roy, 2006). However, pharmacokinetic parameters of GAT and its milk penetration especially in mastitic goats are not available.
Hence the presents study was undertaken to determine the pharmacokinetic study and milk penetration of GAT following single intravenous (i.v.) administration in healthy and mastitic goats.

\section{Materials and Methods}

\section{Animals}

Twelve clinically healthy Black Bengal lactating goats (14-20 $\mathrm{kg}$ ) of 2 to 2.5 years were used in this study were provided green fodder, routine grazing (daily for six hours) and balanced ration (2 parts wheat husk, 1 part groundnut cake and 1 part crushed maize). Water was provided ad libitum. The mean temperature and relative humidity of experimental animal room were $22-28^{\circ} \mathrm{C}$ and $65-92 \%$, respectively.

\section{Drugs used}

Gatiquin ${ }^{\circledR}$ infusion (Cipla pharmaceutical Ltd., India) was injected i.v. at the dose of $10 \mathrm{mg} / \mathrm{kg}$ bodyweight (b.w.) to each of six healthy and mastitic goats.

\section{Experimental induction of mastitis in goats}

Mastitis was induced in six clinically healthy lactating goats by Coagulase positive Staphyloccous aureus (procured from Indian Veterinary Research Institute, Izzatnagar, U.P., India) by method of Sar et al. (2006) with some modifications. The stock culture contained

*Corresponding authors: Dr. B. K. Roy, Dept. of Pharmacology \& Toxicology, College of Veterinary Science \& A. H., Ranchi - 834006, Jharkhand, India, Tel: +91-651-2450759; Fax: +91 -651-2450759; E-mail: roybk2001@yahoo.co.in

Received March 23, 2010; Accepted April 25, 2010; Published April 25, 2010

Citation: Singh V, Ram M, Roy BK, Singh KK (2010) Effect of Induced Mastitis on Disposition Kinetics of Gatifloxacin Following Intravenous Administration in Goats. J Bioanal Biomed 2: 044-048. doi:10.4172/1948-593X.1000020

Copyright: (C) 2010 Singh V, et al. This is an open-access article distributed unde the terms of the Creative Commons Attribution License, which permits unrestricted use, distribution, and reproduction in any medium, provided the original author and source are credited. 
Citation: Singh V, Ram M, Roy BK, Singh KK (2010) Effect of Induced Mastitis on Disposition Kinetics of Gatifloxacin Following Intravenous Administration in Goats. J Bioanal Biomed 2: 044-047. doi:10.4172/1948-593X.1000020

$26 \times 10^{5}$ colony forming units (cfu) of $S$. aureus. $10^{-5}$ dilution was used for induction of mastitis. After $6 \mathrm{~h}$ animals showed the symptoms of inflammation (swelling and pain), fever, anorexia and agalactia. Mastitis was confirmed by the standard tests (California Mastitis Test, Somatic Cell Count, Catalase Test and Bromocresol Purple Test). On day $3^{\text {rd }}$ mastitis was fully induced and pharmacokinetic study of GAT was conducted on day 4 .

\section{Collection of experimental samples}

The blood samples were collected in heparinized test tubes by jugular venipuncture and milk samples were collected manually from both the quarters in sterile test tubes by hand milking at $0,2.5,5$, $10,15,20,30,45 \mathrm{~min}$ and $1,2,3,4,6,8,12,24,36,48$ and $60 \mathrm{~h}$ following drug administration.

\section{Analytical methods}

The method of Santoro et al. (2006) with some modifications was used for the quantitative estimation of gatifloxacin on HPLC in plasma and milk after i.v. administration. The concentrations of gatifloxacin were determined by RP- HPLC with UV-VIS detector. The sensitivity of the method was $0.065 \mu \mathrm{g} / \mathrm{ml}$ and linearity was 0.999 in plasma and 0.9987 in milk are presented in Figure 1 and Figure 2.

\section{Pharmacokinetic analysis}

The pharmacokinetic parameters of GAT in goats were calculated by computer software as per methods described by Gibaldi and Weintraub, 1971; Notari, 1980; Baggot, 1977.

\section{In vitro plasma protein binding}

The plasma protein binding of GAT was determined by the

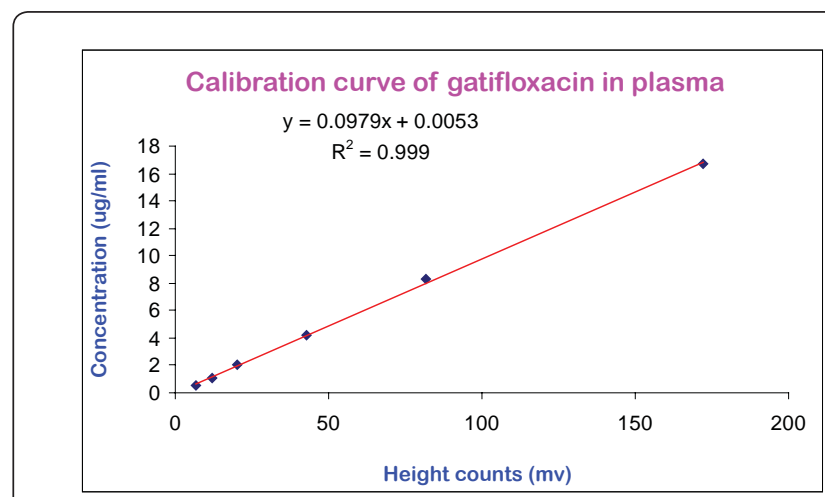

Figure 1

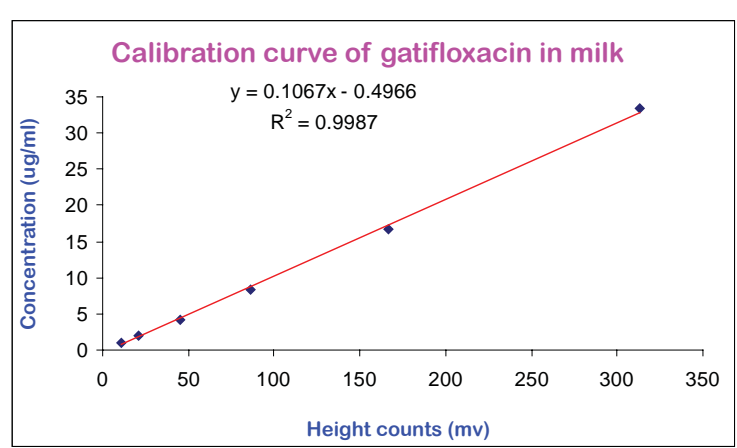

Figure 2

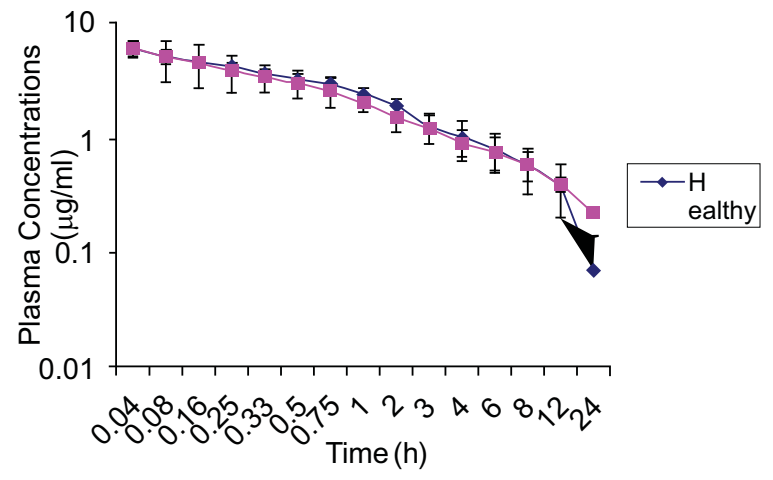

Figure 3: Semilogarithmic plot of comparative plasma concentrations $(\mu \mathrm{g} / \mathrm{ml})$ (Mean \pm SD) of GAT in healthy and mastitic goats $(n=6)$ after single i.v. dose $(10 \mathrm{mg} / \mathrm{kg})$ administration.

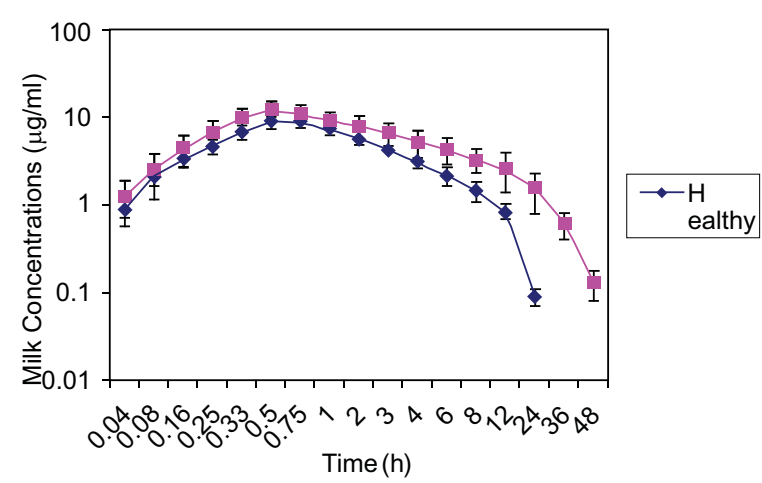

Figure 4: Semilogarithmic plot of comparative milk concentrations $(\mu \mathrm{g} / \mathrm{ml})$ (Mean \pm SD) of GAT in healthy and mastitic goats $(n=6)$ after single i.v. dose $(10 \mathrm{mg} / \mathrm{kg})$ administration.

"equilibrium dialysis" technique as described by Davis, (1943) and Sisodia et al. (1965).

Plasma standard solutions of GAT were prepared in the concentration of $6.25,12.5,25$ and $50 \mu \mathrm{g} / \mathrm{ml}$. The concentrations of drug in plasma and buffer were read with the help of HPLC and plasma protein binding of drug was calculated by the formula given by Linkenheinmer et al. (1965).

Plasma Protein binding $=\frac{\text { Conc. of drug in plasma }- \text { conc. of drug in buffer }}{\text { Conc. of drug in plasma }} \times 100$

\section{Stastistical method}

T-test was done to see the effect of mastitis on pharmacokinetic variability of GAT according to standard method of Snedecor and Cochran, (1994).

\section{Results}

The semi-logerithmic plot of comparative gatifloxacin concentration in plasma and milk samples is presented in Figure 3 and Figure 4. In milk GAT was detected for $24 \mathrm{~h}$ in healthy and for $48 \mathrm{~h}$ in mastitic condition. Mean pharmacokinetic parameters of GAT in plasma and milk of healthy and mastitic goats are presented in Table 1. The zero-time plasma concentrations $\left(\mathrm{C}^{0} \mathrm{p}\right)$ in healthy and mastitic goats were $7.27 \pm 1.72$ and $7.34 \pm 1.91 \mu \mathrm{g} / \mathrm{ml}$ respectively. The elimination half-life $\left(\mathrm{t}_{1 / 2} \beta\right)$ in mastitic goats $(5.82 \pm 0.67 \mathrm{~h})$ was significantly $(\mathrm{p}<0.01)$ higher to that in healthy goats $(4.54 \pm 0.75$ 


\section{Journal of Bioanalysis \& Biomedicine - Open Access}

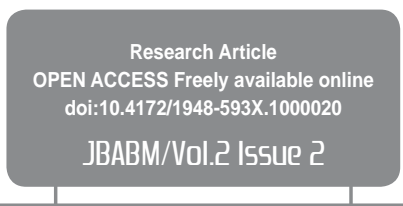

\begin{tabular}{|c|c|c|}
\hline Kinetic parameters & Healthy & Mastitic \\
\hline \multicolumn{3}{|l|}{ Plasma } \\
\hline $\mathrm{C}^{\circ} \mathrm{p}(\mu \mathrm{g} / \mathrm{ml})$ & $7.27 \pm 1.72$ & $7.34 \pm 1.91$ \\
\hline$t_{1 / 2} \alpha(h)$ & $0.14 \pm 0.04$ & $0.09 \pm 0.06$ \\
\hline$t_{1 / 2} \beta(h)$ & $4.54 \pm 0.75$ & $5.82 \pm 0.67^{* *}$ \\
\hline $\mathrm{Vd}_{\text {area }}(\mathrm{L} / \mathrm{kg})$ & $3.92 \pm 0.69$ & $4.76 \pm 1.03$ \\
\hline $\mathrm{AUC}(\mathrm{mg} / \mathrm{L} . \mathrm{h})$ & $17.40 \pm 4.51$ & $18.03 \pm 2.06$ \\
\hline $\mathrm{Cl}_{\mathrm{B}}(\mathrm{ml} / \mathrm{kg} / \mathrm{min})$ & $10.12 \pm 2.52$ & $9.37 \pm 1.12$ \\
\hline $\mathrm{K}_{12}\left(\mathrm{~h}^{-1}\right)$ & $4.54 \pm 2.26$ & $5.77 \pm 2.57$ \\
\hline $\mathrm{K}_{21}\left(\mathrm{~h}^{-1}\right)$ & $3.19 \pm 0.78$ & $3.71 \pm 2.24$ \\
\hline $\mathrm{K}_{2}\left(\mathrm{~h}^{-1}\right)$ & $0.39 \pm 0.12$ & $0.36 \pm 0.08$ \\
\hline MRT(h) & $6.84 \pm 1.23$ & $9.63 \pm 1.52^{\star *}$ \\
\hline T/P ratio & $1.55 \pm 0.64$ & $1.85 \pm 0.71$ \\
\hline \multicolumn{3}{|l|}{ Milk } \\
\hline $\mathrm{Cm}_{\max }(\mu \mathrm{g} / \mathrm{ml})$ & $9.17 \pm 1.41$ & $12.78 \pm 3.11^{*}$ \\
\hline $\mathrm{t}_{1 / 2 \beta \mathrm{M}}(\mathrm{h})$ & $3.67 \pm 0.22$ & $8.20 \pm 0.51^{* *}$ \\
\hline $\mathrm{Vd}_{\text {aream }}(\mathrm{L} / \mathrm{kg})$ & $1.32 \pm 0.17$ & $1.29 \pm 0.43$ \\
\hline $\mathrm{AUC}_{\mathrm{M}}(\mathrm{mg} / \mathrm{L} . \mathrm{h})$ & $40.68 \pm 4.17$ & $104.93 \pm 36.67^{* *}$ \\
\hline MRT(h) & $5.27 \pm 0.37$ & $12.49 \pm 0.94^{* *}$ \\
\hline $\mathrm{Cl}_{\mathrm{BM}}(\mathrm{ml} / \mathrm{kg} / \mathrm{min})$ & $4.14 \pm 0.43$ & $1.78 \pm 0.57^{* *}$ \\
\hline $\mathrm{T}_{\max M}(\mathrm{~h})$ & $0.67 \pm 0.32$ & $0.54 \pm 0.09$ \\
\hline
\end{tabular}

${ }^{*} \mathrm{P}<0.05 ;{ }^{* *} \mathrm{P}<0.01$.

$\mathrm{C}^{\circ} \mathrm{p}(\mu \mathrm{g} / \mathrm{ml})=$ Zer-time plasma concentration, $\mathrm{t}_{1 / 2} \alpha(\mathrm{h})=$ Distribution plasma half-life, $t_{1} \beta(h)=$ Elimination plasma half-life, $V d_{d}=$ Volume of distribution based on area under curve, $\mathrm{AUC}=$ Area under curve, $\mathrm{Cl}_{\mathrm{B}}=$ Total body clearance rate $\mathrm{K}_{12}=$ Rate constant for transfer of drug from central to peripheral compartment, $\mathrm{K}_{21}=$ Rate constant for transfer of drug from peripheral to central compartment, $\mathrm{K}_{2}=$ elimination from central compartment, $M R T=$ Mean residence time, $A^{2} U C / M I C=$ Ratio between area under curve and minimum inhibitory concentration, T/P ratio $=$ Tissue to plasma ratio. $t_{1} \beta M=$ elimination half-life in milk; $V d=$ volume of distribution based on area under curve in milk; $\mathrm{Cl}_{\mathrm{BM}} \mathrm{t}$, $=$ total clearance in milk; $\mathrm{Cm}_{\max }=$ maximumr milk concentration; $\mathrm{T}_{\max }=$ time to peak concentration in milk.

Table 1: Plasma pharmacokinetic parameters (Mean \pm S.D.) of GAT after single dose $(10 \mathrm{mg} / \mathrm{kg})$ i.v. administration in healthy and mastitic goats.

h). Total body clearance (ClB) did not differ significantly in mastitic $(9.37 \pm 1.12 \mathrm{ml} / \mathrm{kg} / \mathrm{min})$ and healthy goats $(10.12 \pm 2.52 \mathrm{ml} / \mathrm{kg} / \mathrm{min})$. Apparent volume of distribution $\left(\mathrm{Vd}_{\text {area }}\right)$ in mastitic and healthy goats were $4.76 \pm 1.03 \mathrm{~L} / \mathrm{kg}$ and $3.92 \pm 0.69 \mathrm{~L} / \mathrm{kg}$ respectively. The ratio of $\mathrm{K}_{12} / \mathrm{K}_{21}$ in mastitic goats $(1.75 \pm 0.67)$ was slightly higher than healthy $(1.31 \pm 0.70)$. Plasma protein binding of GAT was found to be $25 \%$.

Maximum milk concentration $\left(\mathrm{Cm}_{\max }\right)$ in mastitic goats $(12.78$ $\pm 3.11 \mu \mathrm{g} / \mathrm{ml}$ ) was significantly $(\mathrm{p}<0.05)$ higher than healthy goats $(9.17 \pm 1.41 \mu \mathrm{g} / \mathrm{ml})$. Milk half-life $\left(\mathrm{t}_{1 / \beta \mathrm{M}}\right)$ in mastitic goats $(8.20 \pm$ $0.51 \mathrm{~h})$ was significantly $(\mathrm{p}<0.01)$ higher than healthy $(3.67 \pm 0.22$ h). The value of AUC in mastitic milk $(104.93 \pm 36.67 \mathrm{mg} / \mathrm{L} . \mathrm{h})$ was significantly $(\mathrm{p}<0.01)$ higher than healthy $(40.68 \pm 4.17 \mathrm{mg} / \mathrm{L} . \mathrm{h})$. Time for attainment of maximum milk concentration $\left(t_{\max \mathrm{m}}\right)$ in healthy goats was $0.67 \pm 0.32 \mathrm{~h}$, whereas in mastitic goats it was obtained earlier $(0.54 \pm 0.09 \mathrm{~h})$.

\section{Discussion}

The semi-logarithmic plot of plasma levels time profile of GAT evident bi-exponential decay curve and the pharmacokinetic parameters were described based on two compartment open model in healthy and mastitic goats (Baggot, 1977). The plasma half-life $\left(t_{1 / 2} \beta\right)$ of GAT was significantly $(\mathrm{p}<0.01)$ longer in case of mastitic goats as compared to healthy, decreased $\mathrm{ClB}$ in mastitic goats also supports the finding. The $\mathrm{K}_{12} / \mathrm{K}_{21}$ ratio obtained in this study indicated a faster drug transfer from central to peripheral compartment than from peripheral to central compartment. The plasma protein binding of GAT was found to be $25 \%$. In humans also the serum protein binding is approximately $20 \%$ (Grasela, 2001). This lower value of plasma protein binding is suggesting that the drug in not remaining in the vascular compartment only, rather it is being distributed widely. It is further supported by slight increase in the value of $\mathrm{Vd}_{\text {area }}$ in mastitic goats.

The T/P ratio in mastitic goats was higher than healthy, exhibiting more concentration of drug in tissues than plasma, which would be of significance while considering the case of mastitis where there is need of concentration of more drug in milk than plasma.

Milk half-life $\left(t_{1 / \beta M}\right)$ of GAT was also found to be significantly longer in mastitic goats as compared to healthy. However, GAT was maintained for a longer period in milk than plasma of mastitic goats. Similar results were also reported in subjects suffering with pneumococcal meningitis, $t_{1 / \beta}$ of GAT in CSF (3.8 to $5.6 \mathrm{~h}$ ) was found higher as compared to blood ( 2.7 to $3.2 \mathrm{~h}$ ) (Lutsar et al., 1998). The $t_{1 / 2 \beta}$ of GAT in plasma $(6.8 \mathrm{~h})$ has also been found to be lower as compared to that in inflammatory fluid (7.2 h) (Wise et al., 1999). The $\mathrm{Cm}_{\max }$ of GAT in case of mastitic goats was significantly higher than healthy goats. The various solute transport and secretion processes involved in milk production offer pathways for the movement of drug molecules from plasma to milk (McManaman and Neville, 2003). It may be mentioned that un-ionized drug molecule is easily diffusible across the membranes and the extent of ionization depends upon $\mathrm{pH}$ of the fluids in the compartments. GAT has two Pka values, Pka1-6.0 and $\mathrm{Pka}_{2}-9.2$. The plasma $\mathrm{pH}$ is relatively constant (7.4) because of its buffering system. Milk $\mathrm{pH}$, however, is more variable and increase markedly in mastitic conditions. The results obtained in this experiment strengthen the argument that GAT passed from blood to milk via non-ionic diffusion. Increased permeability of the mammary epithelial cells under the effect of several chemical mediators (Zhao and Lacasse, 2007) may contribute to some extent, in the increased milk concentration of GAT in mastitic goats. There is an additional fact that polymorphonuclear neutrophils uptake GAT, like other fluoroquinolones. The active uptake of GAT by the neutrophils is beneficial from treatment point of view. The $t_{1 / 2}$ milk/ $\mathrm{t}_{1 / 2 \text { plasma }}$ ratio (1.41) also indicated drug persistence in mastitic milk for longer period than in plasma. Reports are available that ibafloxacin penetrated poorly from blood into milk after i.v. administration in goats and persisted for short time in milk than in plasma $\left(t_{1 / 2}\right.$ milk/t $t_{1 / 2}$ plasma < 1) (Marin et al., 2007a). It may be mentioned that quinolones are concentration-dependent killers and for effective systemic treatment of mastitis drug should extensively penetrate the inflamed mammary gland. In this experiment it was found that the AUCmilk/ AUCplasma ratio in mastitic goats was 5.82 which indicated that the drug penetrated milk extensively. For orbifloxacin administered i.v. $\mathrm{AUC}_{\text {milk }} / \mathrm{AUC}_{\text {plasma }}$ ratio was 1.02 (Marin et al., 2007b). The minimum inhibitory concentration of GAT for $S$. aureus has been reported to be $0.1 \mu \mathrm{g} / \mathrm{ml}$ (Tsurumaki et al., 2000; Boubakar et al., 2006). AUC/MIC is one of the most important efficacy predictor with the rate of clinical cure being $>80 \%$, The AUC/MIC ratio of GAT in plasma and milk of mastitic goats were 180 and 1049 respectively, which indicated good therapeutic efficacy.

On the basis of above observed findings, it can be said that GAT showed excellent milk penetration, maintenance of higher concentration for a longer time period and slower elimination from mastitic goats. Thus, it would be helpful for treating mastitis in goats caused by $S$. aureus.

\section{Acknowledgements}

Authors acknowledge Vice-chancellor, B.A.U., Ranchi and Dean, Ranchi Veterinary College, Ranchi, Jharkhand, India for providing the funds and facilities for this experiment.

\section{References}

1. Aliabadi F, Lees P (2001) Pharmacokinetics and pharmacodynamics of danofloxacin in serum and tissue fluids of goats following intravenous and 
Citation: Singh V, Ram M, Roy BK, Singh KK (2010) Effect of Induced Mastitis on Disposition Kinetics of Gatifloxacin Following Intravenous Administration in Goats. J Bioanal Biomed 2: 044-047. doi:10.4172/1948-593X.1000020

intramuscular administration. Am J Vet Res 62: 1979-1989. »CrossRef » PubMed " Google Scholar

2. Baggot JD (1977) Principles of drug disposition in domestic animals: The basis of Veterinary Clinical Pharmacology. ( $1^{\text {ste }}$ dn $)$, W.B. Saunders company, Philadelphia, London, Toranto. » CrossRef » PubMed » Google Scholar

3. Barkema HW, Schukken YH, Zadoks RN (2006) The role of cow, pathogen and treatment regimen in the therapeutic success of bovine Staphylococcus aureus mastitis. J Dairy Sci 89: 1877-95. "CrossRef » PubMed » Google Scholar

4. Ba BB, Arpin C, Vidaillac C, Chausse A, Saux MC, et al. (2006) Activity of Gatifloxacin in an In Vitro Pharmacokinetic-Pharmacodynamic Model against Staphylococcus aureus Strains either Susceptible to Ciprofloxacin or Exhibiting Various Levels and Mechanisms of Ciprofloxacin Resistance. Antimicrob Agents Chemother 50: 1931-1936. » CrossRef » PubMed » Google Scholar

5. Brown SA (1996) Fluoroquinolones in animal health. Veterinary Pharmacology and Therapeutics 19: 1-14. "CrossRef » PubMed " Google Scholar

6. Davis BD (1943) The binding of sulfonamide drugs to plasma proteins. A factor in determining the distribution of drug in the body. J Clin Invest 22: 753-762. "CrossRef » PubMed " Google Scholar

7. Drusano GL, Johnson DE, Rosen M, Standiford HC (1993) Pharmacodynamics of a fluoroquinolone antimicrobial agent in a neutropenic rat model of Pseudomonas sepsis. Antimicrob Agents Chemother 37: 483-490. " CrossRef » PubMed » Google Scholar

8. Gibaldi M, Weintraub H (1971) Some considerations to determination and significance of biological half life. Pharm Science 60: 624-626. „ CrossRef » PubMed " Google Scholar

9. Grasela DM (2001) Clinical pharmacology of gatifloxacin. Clinical Pharmacology 31: 51-58. "CrossRef » PubMed » Google Scholar

10. Kerro Dogo O, Van Dijk JE, Nederbragt H (2002) Factors involved in the early pathogenesis of bovine Staphylococcus aureus mastitis with emphasis on bacterial adhesion and invasion. A review Vet Q 24: 181-198. ”CrossRef » PubMed » Google Scholar

11. Loo KC, Cario AC, Zhang F, Walters JD (1997) Regulation of ciprofloxacin uptake in human promyelocytic leukemia cells and polymorphonuclear leucocytes. Leucocyte Biol 61: 619-623. » CrossRef » PubMed » Google Scholar

12. Lutsar I, Friedland IR, Wubbel L, McCoig CC, Jafri HS, et al. (1998) Pharmacodynamics of gatifloxacin in cerebrospinal fluid in experimental cephalosporin-resistant pneumococcal meningitis. Antimicrob Agents Chemother 42: 2650-2655. " CrossRef " PubMed » Google Scholar

13. Marín P, Cárceles CM, Escudero E, Fernández-VarónE (2007)Pharmacokinetics and milk penetration of Ibafloxacin after intravenous administration in lactating goats. Can J Vet Res 71: 74-76. " CrossRef » PubMed » Google Scholar

14. Marín P, Escudero E, Fernández-Varón E, Cárceles CM (2007) Pharmacokinetics and milk penetration of orbifloxacin after intravenous intramuscular and subcutaneous administration in lactating goats. J Dairy Sci 90: 4219-4225. » CrossRef » PubMed » Google Scholar

15. McManaman JL, Neville MC (2003) Mammary physiology and milk secretion. Advanced Drug Delivary Review 55: 629-641. „ CrossRef » PubMed » Google Scholar
16. Memin E, Panteix G, Revol A (1997) Carrier-mediated system for pefloxacin uptake in human monocytes. J Antimicrob Chemother 40: 263-268. "CrossRef "PubMed » Google Scholar

17. Mullarky IK, Su C, Frieze N, Park YH, Sordillo LM (2001) Staphylococcus aureus agr genotypes with enterotoxin production capabilities can resist neutrophil bactericidal activity. Infect Immun 69: 45-51. » CrossRef » PubMed » Google Scholar

18. Notari RE (1980) Biopharmaceutics and Clinical pharmacokinetics ( $3^{\text {rd }}$ edn). Marcel Dekker, INC, New York. " CrossRef » PubMed » Google Scholar

19. Perry CM, Balfour JAB, Lamb HM (1999) Gatifloxacin. Drugs 58: 683-696. "CrossRef » PubMed » Google Scholar

20. Santoro RM, Kassab NM, Singh AK, Kedor-Hackmam ERM (2006) Qantitative determination of gatifloxacin, levofloxacin, lomefloxacin and pefloxacin fluoroquinolonic antibiotics in pharmaceutical preparations by HPLC. Department of pharmacia and pharmaceutics. Univ. of Sao Paulo, Brazil. "CrossRef » PubMed » Google Scholar

21. Sar TK, Mandal TK, Das SK, Chakraborty AK, Bhattacharyya A (2006) Pharmacokinetics of ceftriaxone in healthy and mastitic goats with specia reference to its interaction with Polyherbal drug (Fibrosin). Intern J Appl Res Vet Med 4: 142-154. "CrossRef » PubMed » Google Scholar

22. Shearer JK, Harris B (2008) Mastitis in Dairy Goats. Large Animal Clinica Sciences, Institute of Food and Agricultural Sciences, University of Florida. »CrossRef » PubMed » Google Scholar

23. Sisodia CS, Millen GE, Stowe CM (1965) Protein binding of sulfonamides and quinine in bovine milk and plasma. Indian Vet $\mathrm{J}$ 42: 7-16. "CrossRef " PubMed » Google Scholar

24. Snedecor CW, Cochran WG (1994) Statistical methods (6 $6^{\text {th }}$ edn). lowa State Univ. Press Anes, USA. " CrossRef " PubMed " Google Scholar

25. Tsurumaki $Y$, Manda H, Takei M, Hosaka M (2000) In vitro antimicrobial activity of gatifloxacin against 875 clinical isolates from respiratory tract, urinary tract and surgical infections during 1997-98 in Japan. J Antimicrob Chemother 45: 685-689. »CrossRef » PubMed » Google Scholar

26. Verma DK, Roy BK (2006) Milk kinetics of gatifloxacin after single dose intravenous administration in healthy and febrile goats. Indian J Pharmacol 38 366-367. " CrossRef » PubMed " Google Scholar

27. Wise R, Andrews JM, Ashby JP, Marshall (1999) A study to determine pharmacokinetics and inflammatory fluid penetration of gatifloxacin following single oral dose. J Antimicrob Chemother 44: 701-704. »CrossRef » PubMed » Google Scholar

28. Yancey RJ, Sanchez MS, Ford CW (1991) Activity of antibiotics against Staphylococcus aureus within polymorphonuclear neutrophils. Eur J Clin Microbiol Infect Dis 10: 107-113. » CrossRef » PubMed » Google Scholar

29. Zhao X, Lacasse P (2007) Mammary tissue damage: Dairy bovine mastitis Cause and control. J Animal Science 4: 17785603. "CrossRef " PubMed " Google Scholar 